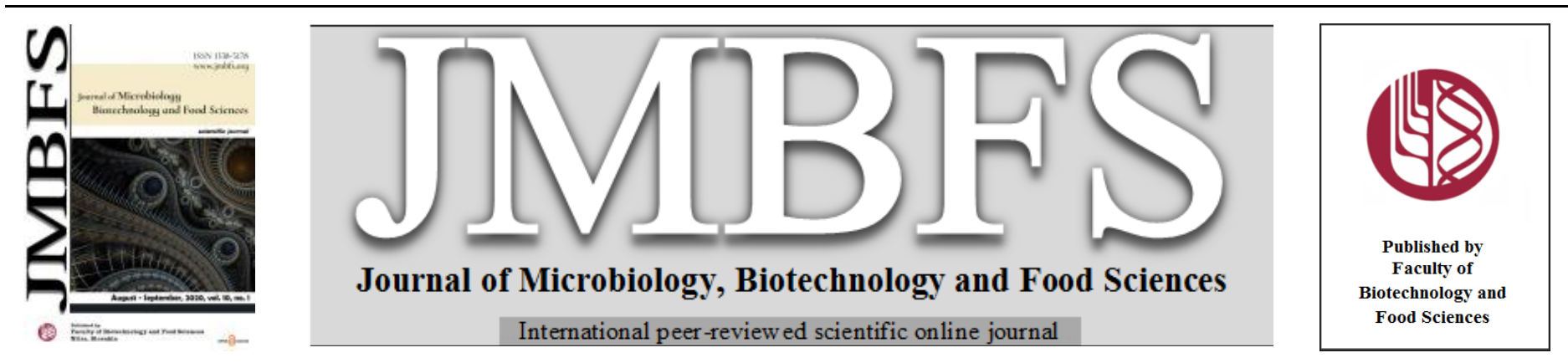

\title{
EVALUATION OF THE SENSITIVITY OF NITROCELLULOSE MEMBRANE LOW-COST ALTERNATIVES USED IN TISSUE BLOT IMMUNOASSAY (TBIA) FOR DETECTION OF SOME PLANT VIRUSES
}

\author{
Maha Kawanna $*^{l}$ and Hosny Younes ${ }^{2}$ \\ Address(es): \\ ${ }^{1}$ Alexandria University, Faculty of Agriculture (El-Shatby), Department of Plant Pathology, Aflatoon street, 21545, Alexandria, Egypt. \\ ${ }^{2}$ Alexandria University, Faculty of Agriculture (Saba Basha), Department of Agriculture Botany, Saba Basha, Alexandria, Egypt.
}

*Corresponding author: mahakawanna@yahoo.com

doi: 10.15414/jmbfs.2020.10.1.68-72

\section{ARTICLE INFO}

Received 8. 7. 2019

Revised 7. 3. 2020

Accepted 12.3. 2019

Published 1. 8. 2020

Regular article

OPEN $\partial_{\text {AcCESS }}$

\begin{abstract}
In an attempt of reducing the cost of tissue blot immunoassay (TBIA), some kinds of papers as alternative solid phases in place of nitrocellulose membrane (NCM), were tested for detection of three viruses: Cowpea mosaic virus (CPMV), Tomato mosaic virus (ToMV) and Zucchini yellow mosaic virus (ZYMV). Most of the examined papers developed positive reaction with all tested viruses. Canson paper $\left(150 \mathrm{~g} / \mathrm{m}^{2}\right.$ and $\left.300 \mathrm{~g} / \mathrm{m}^{2}\right)$ were sensitive for detection of the tested viruses as NCM and persist in good condition during the processing. Filter paper (Whatman No. 1), local drawing paper $\left(60 \mathrm{~g} / \mathrm{m}^{2}\right)$, photocopy paper $\left(80 \mathrm{~g} / \mathrm{m}^{2}\right),\left(56 \mathrm{~g} / \mathrm{m}^{2}\right)$ and $\left(70 \mathrm{~g} / \mathrm{m}^{2}\right)$ were very weak and need to taking care in handling. High glossy photo paper $\left(200 \mathrm{~g} / \mathrm{m}^{2}\right)$ was not effective however, it did not show any infected or healthy tissue print. Good results were obtained when both faces of NCM and Canson paper $\left(300 \mathrm{~g} / \mathrm{m}^{-2}\right)$ were printed with all tested viruses. TBIA could detect CPMV in infected leaves using the unused face of NCM previously processed with 7 or 11 years ago. CPMV, ToMV and ZYMV were detected 2, 4, 6, 8 and16 days after inoculation with NCM and Canson paper $\left(300 \mathrm{~g} / \mathrm{m}^{-2}\right)$. Also, the tested viruses were detected in leaf, petiole, stem and root of infected plants. ToMV could be detected using NCM and Canson paper $\left(300 \mathrm{~g} / \mathrm{m}^{-2}\right)$ in naturally infected tomato plant samples.
\end{abstract}

Keywords: TBIA, CPMV, ToMV, ZYMV, alternative solid phases

\section{INTRODUCTION}

Accurate detection is an essential step to control the plant viruses (Jeong $\boldsymbol{e t}$ al., 2014). It is very imperative to recognize a sensitive, simple, reliable, inexpensive method for detection of the virus in the different parts of the infected plants (Aboul-Ata et al., 2011).

Tissue blot immunoassay (TBIA) is widely used for detection of plant viruses in various plant tissues. It could apply even in poorly equipped laboratories. TBIA is simple, sensitive, does not require elaborate sample preparation or extraction (Lin et al., 1990; Hsu and Lawson, 1991; Makkouk et al., 1993; Hu et al., 1997; D'Onghia et al., 2001; Hsu, 2009; Bin et al., 2015). In TBIA, nitrocellulose membrane (NCM, $0.45 \mathrm{~nm}$ ) is usually using as a solid support for the test.

Cowpea mosaic virus (CPMV), which a member of the Comovirus genus and Secoviridae family, is one of the most commonly virus diseases of cowpea, it decreases the yield by up to $95 \%$ (Kammen et al., 2001). Tomato mosaic virus (ToMV) in the Tobamovirus genus belongs to family Virgaviridae (Li et al., 2015) is a serious and extremely spreadable disease. The tomato fruits of plants infected with ToMV show yellowish blotches and necrotic spots and the interior of the fruit become brown, also, it causes severe reduction of the yield (Broadbent, 1976). Zucchini yellow mosaic virus (ZYMV) (genus: Potyvirus; family: Potyviridae) is a major viral pathogen of cucurbits. It causes severe stunting of plants and distortion of the fruits which led to high losses of productivity (Desbiez and Lecoq, 1997).

The objectives of the present study were to evaluate the sensitivity of different types of low-cost papers as solid phases alternative to the expensive NCM for detection of CPMV, ToMV and ZYMV, to assess the possibility of using both faces of the best papers, and to detect the sensitivity of the previously used NCM for detection of the tested viruses.

\section{MATERIALS AND METHODS}

\section{Maintenance and inoculation of the viruses}

Three viruses, namely CPMV, ToMV and ZYMV used in this study were obtained from the collection of Virology Lab., Plant Pathology Department, Faculty of Agriculture, Alexandria University. CPMV was maintained on Vigna unguiculate, while ToMV on Lycopersicon esculentum cv. Super strain B and ZYMV was maintained on Cucurbita pepo cv. Eskandrani, which served as virus source plants for further studies.

Inocula were prepared by grinding infected leaf tissues in phosphate buffer $0.02 \mathrm{M}(\mathrm{pH} 7.0)$ with a mortar and pestle. Leaves of plants to be inoculated were first dusted with carborandum (600 mesh) and then inoculated with a freshly prepared inoculum using forefinger.

\section{Source of antisera}

Antisera used in this study were locally produced in Plant virology Lab., Plant Pathology Department, Faculty of Agriculture, Alexandria University, Egypt.

\section{Tissue blot immunoassay (TBIA)}

TBIA first described by Lin $\boldsymbol{e t}$ al. (1990), using the following steps and washes in between: (1) plant samples (leaves, stems, petioles or roots) from healthy and infected plants were cut by hand with razor blade in a steady motion to obtain a single plane cut surface and blotting the exposed cut edges onto the nitrocellulose membrane (NCM, $0.45 \mathrm{~nm}$, Bio- Rod Laboratories, Richmond, CA) or tested papers, (2) treated NCM or papers were then placed in blocking buffer $\{2 \%$ bovine serum albumin (BSA) and triton X-100 solution in Tris buffer saline (TBS) $\mathrm{pH} 7.5$ \}, (3) soaking the NCM or papers with the virus antiserum for $2 \mathrm{~h}$, (4) adding the goat anti-rabbit IgG conjugated to alkaline phosphatase, gently agitated for one hour. Finally, the NCM or papers incubated in freshly prepared 5- bromo- 4- chloro- 3- indolyl phosphate (BCIP) and nitro blue tetrazolium (NBT) substrate solution for 15-30 min. After colour development, the reaction was stopped by washing the treated membrane or paper in $0.01 \mathrm{M}$ Tris- $\mathrm{HCI}$ 
containing $0.05 \mathrm{M}$ EDTA, $\mathrm{pH}$ 7.5. The positive reaction of TBIA was indicated by the development of purple colour on the blots. The negative reaction (virusfree samples) developed no or green colour.

\section{The sensitivity of different types of papers as alternative solid phases}

Eight different types of papers were compared with nitrocellulose membrane (NCM, $0.45 \mathrm{~nm}$, Bio- Rod Laboratories, Richmond, CA) for the ability of detection of CPMV, ToMV and ZYMV. These papers were: Canson paper $\left(150 \mathrm{~g} / \mathrm{m}^{2}\right.$ and $\left.300 \mathrm{~g} / \mathrm{m}^{2}\right)$, filter paper (Whatman No. 1), high Glossy photo paper $\left(200 \mathrm{~g} / \mathrm{m}^{2}\right)$ made in China, local drawing paper $\left(60 \mathrm{~g} / \mathrm{m}^{2}\right)$, photocopy paper $\left(80 \mathrm{~g} / \mathrm{m}^{2}\right)$ (double A) manufactured by DA Alizay, France, photocopy paper $\left(56 \mathrm{~g} / \mathrm{m}^{2}\right)$ paper fect-BAHIA SUL and photocopy paper $\left(70 \mathrm{~g} / \mathrm{m}^{2}\right)$ (Smartist) made in Thailand.

The sensitivity of using the two faces of the selected alternative solid phases

Nitrocellulose membrane and Canson paper $\left(300 \mathrm{~g} / \mathrm{m}^{-2}\right)$ were selected to assess the possibility of using the two sides of the paper for detection of CPMV, ToMV and ZYMV. Both faces of the certain papers were printed by healthy and infected leaves.

Testing of the unused faces of previously processed nitrocellulose membrane.

The unused faces of previously processed NCM used 7 or 11 years ago, were printed with CPMV infected leaves and healthy ones.

Detection of CPMV, ToMV and ZYMV in infected plants after different periods of inoculation

The sensitivity of NCM and Canson paper $\left(300 \mathrm{~g} / \mathrm{m}^{-2}\right)$ to detect CPMV, ToMV and ZYMV in infected leaves after $1,2,4,6,8$ and 16 days of mechanical inoculation were examined.

Detection of CPMV, ToMV and ZYMV in different parts of the infected plants

Infected leaves, petioles, stems and roots and healthy ones were printed on NCM and Canson paper $\left(300 \mathrm{~g} / \mathrm{m}^{-2}\right)$ to detect CPMV, ToMV and ZYMV.

\section{Detection of ToMV in naturally infected plants}

NCM and Canson paper $\left(300 \mathrm{~g} / \mathrm{m}^{-2}\right)$ were tested to detect ToMV in naturally infected tomato plants.

\section{RESULTS}

The sensitivity of different types of papers as alternative solid phases

Eight different types of papers and NCM were tested for detection of CPMV ToMV and ZYMV by TBIA. Filter paper (Whatman No. 1), local drawing paper $\left(60 \mathrm{~g} / \mathrm{m}^{2}\right)$, photocopy paper $\left(80 \mathrm{~g} / \mathrm{m}^{2}\right),\left(56 \mathrm{~g} / \mathrm{m}^{2}\right)$ and $\left(70 \mathrm{~g} / \mathrm{m}^{2}\right)$ could indicate purple colour with the tested viruses but they required high care in handling. Also, with these types of paper background was observed. High glossy photo paper $\left(200 \mathrm{~g} / \mathrm{m}^{2}\right)$ did not show any infected or healthy tissue print. Canson paper $\left(150 \mathrm{~g} / \mathrm{m}^{2}\right.$ and $\left.300 \mathrm{~g} / \mathrm{m}^{2}\right)$ were equally sensitive with nitrocellulose membrane and persist in good condition during the assay steps (Figs. 1, 2 and 3). Therefore, Canson paper $\left(300 \mathrm{~g} / \mathrm{m}^{2}\right)$ was selected to use in the subsequent experiments to confirm its sensitivity as compared with NCM.

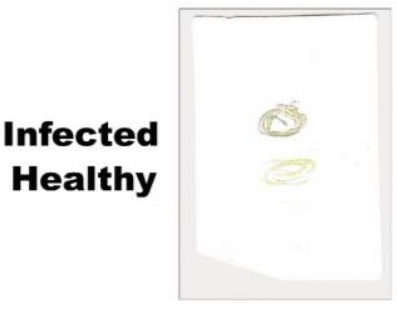

1

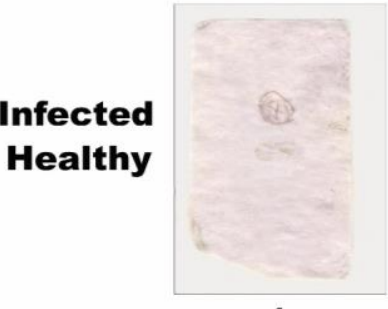

4

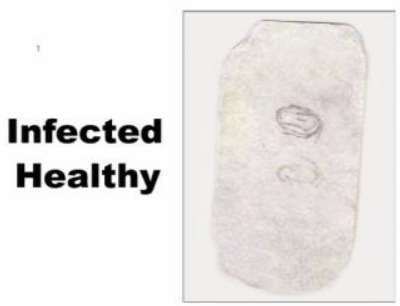

7
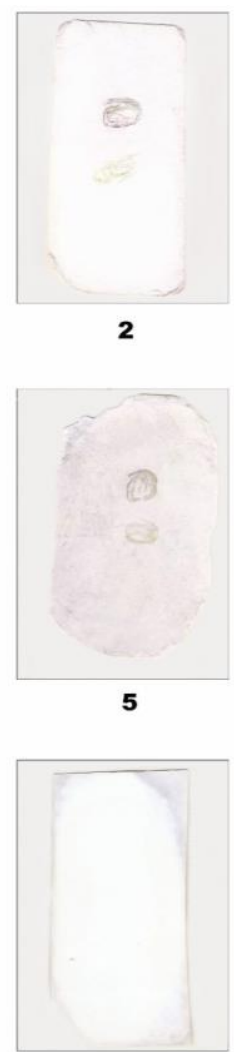

8
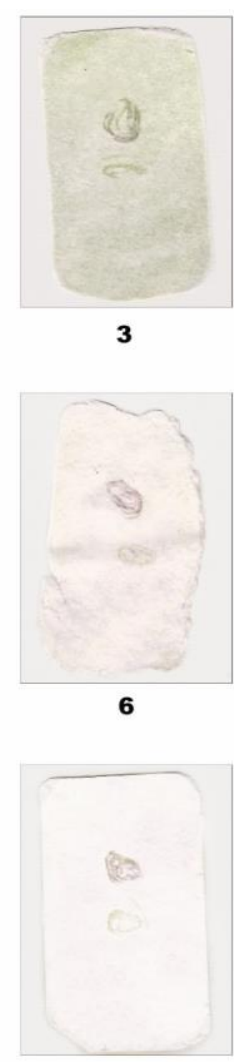

9
Figure 1 Detection of CPMV by TBIA in leaves of infected cowpea plants blotted on different types of solid phases, 1. nitrocellulose membrane (NCM, $0.45 \mathrm{~nm})$, 2.Canson paper $\left(300 \mathrm{~g} / \mathrm{m}^{2}\right)$, 3.filter paper (Whatman No.1), 4.drawing paper $\left(60 \mathrm{~g} / \mathrm{m}^{2}\right), 5$. photocopy paper $\left(80 \mathrm{~g} / \mathrm{m}^{2}\right), 6$.photocopy paper $\left(56 \mathrm{~g} / \mathrm{m}^{2}\right), 7$. photocopy paper $\left(70 \mathrm{~g} / \mathrm{m}^{2}\right)$, 8.high glossy photo paper $\left(200 \mathrm{~g} / \mathrm{m}^{2}\right)$, 9.Canson paper $\left(150 \mathrm{~g} / \mathrm{m}^{2}\right)$.

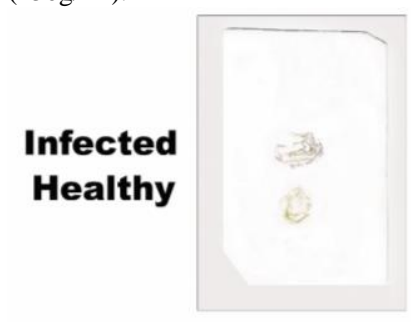

1

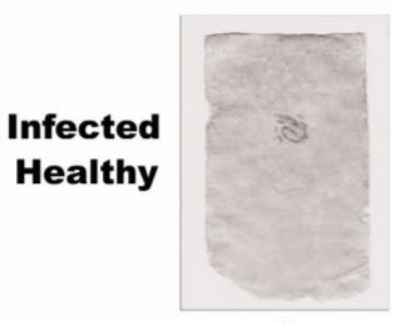

4

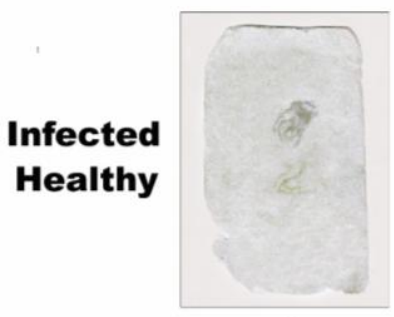

7

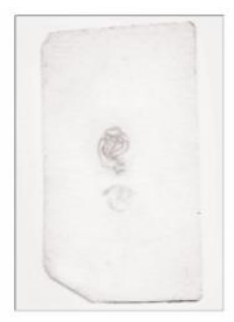

2

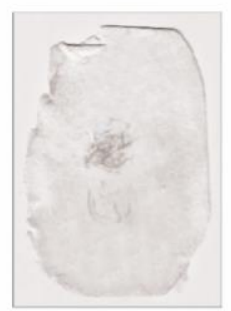

5

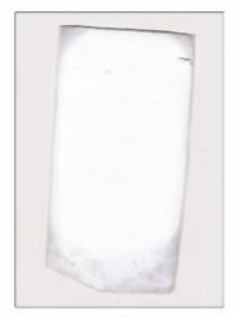

8

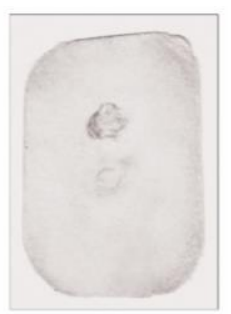

3

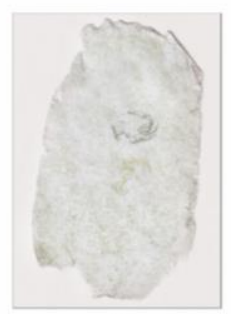

6

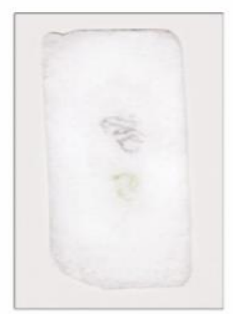

9
Figure 2 Detection of ToMV by TBIA in leaves of infected tomato plants blotted on different types of solid phases, 1 . nitrocellulose membrane (NCM, $0.45 \mathrm{~nm}$ ), 2.Canson paper $\left(300 \mathrm{~g} / \mathrm{m}^{2}\right)$, 3.filter paper (Whatman No.1), 4.drawing paper $\left(60 \mathrm{~g} / \mathrm{m}^{2}\right)$, 5. photocopy paper $\left(80 \mathrm{~g} / \mathrm{m}^{2}\right)$, 6.photocopy paper $\left(56 \mathrm{~g} / \mathrm{m}^{2}\right)$, 7 . photocopy paper $\left(70 \mathrm{~g} / \mathrm{m}^{2}\right)$, 8.high glossy photo paper $\left(200 \mathrm{~g} / \mathrm{m}^{2}\right)$, 9.Canson paper $\left(150 \mathrm{~g} / \mathrm{m}^{2}\right)$. 


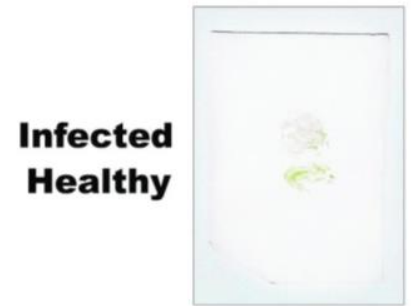

1

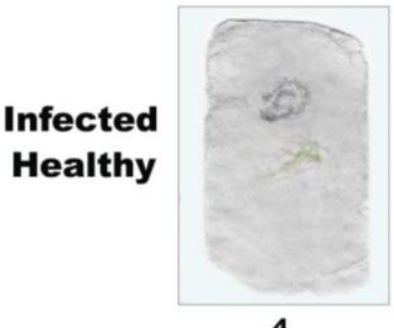

4

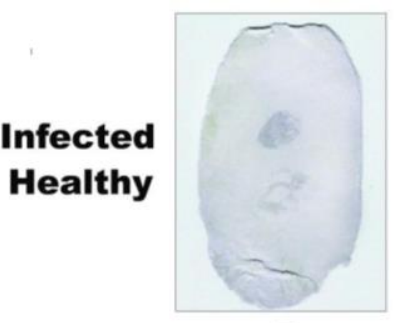

7

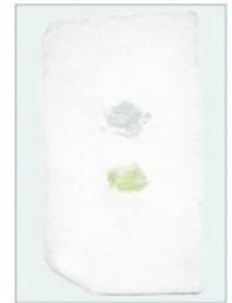

2

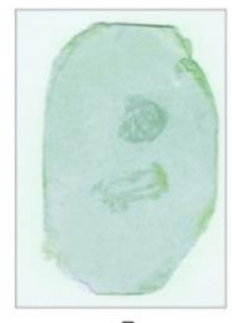

5

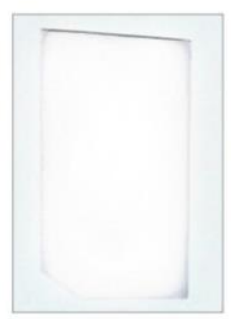

8

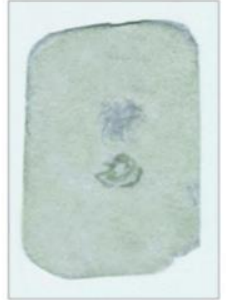

3
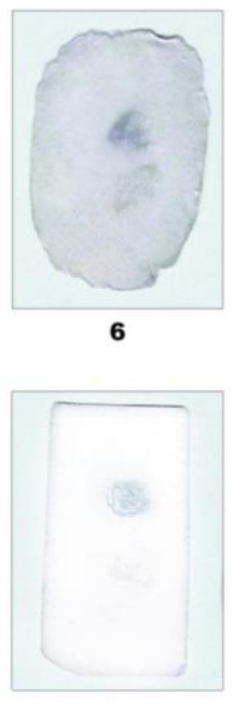

Figure 3 Detection of ZYMV by TBIA in leaves of infected squash plants blotted on different types of solid phases, 1. nitrocellulose membrane (NCM, $0.45 \mathrm{~nm})$, 2.Canson paper $\left(300 \mathrm{~g} / \mathrm{m}^{2}\right)$, 3.filter paper (Whatman No.1), 4.drawing paper $\left(60 \mathrm{~g} / \mathrm{m}^{2}\right), 5$. photocopy paper $\left(80 \mathrm{~g} / \mathrm{m}^{2}\right), 6$.photocopy paper $\left(56 \mathrm{~g} / \mathrm{m}^{2}\right), 7$. photocopy paper $\left(70 \mathrm{~g} / \mathrm{m}^{2}\right)$, 8.high glossy photo paper $\left(200 \mathrm{~g} / \mathrm{m}^{2}\right)$, 9.Canson paper $\left(150 \mathrm{~g} / \mathrm{m}^{2}\right)$.

The sensitivity of using the two faces of the selected alternative solid phases

Positive reactions were obtained on the both faces of NCM and Canson paper $\left(300 \mathrm{~g} / \mathrm{m}^{-2}\right)$ for detection of CPMV, ToMV and ZYMV in infected leaves (Fig. 4).

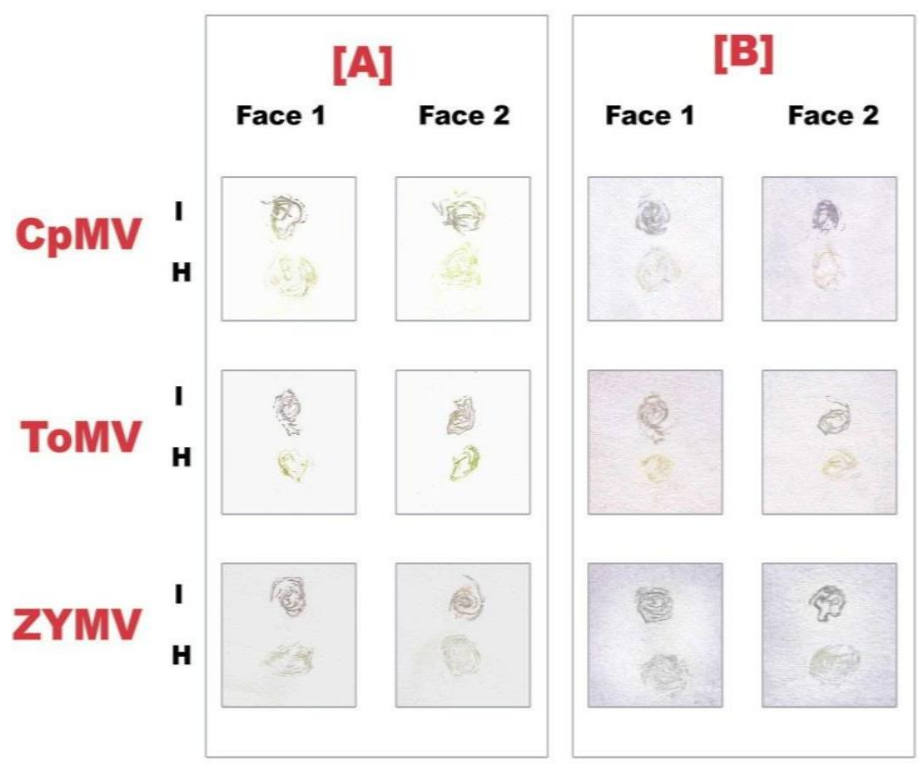

Figure 4 Detection of CPMV, ToMV and ZYMV in leaves of infected plants blotted on both faces of, [A]. Nitrocellulose membrane (NCM), [B]. Canson paper $\left(300 \mathrm{~g} / \mathrm{m}^{2}\right)$. I. Infected plant tissue, H. Healthy plant tissue.

Using the unused faces of previously processed nitrocellulose membrane.

Results indicated the possibility of using the unused face of NCM even after 7 years or 11 years of processing for detection of CPMV. Pronounced purple colour with infected leaf tissues was observed (Fig. 5).

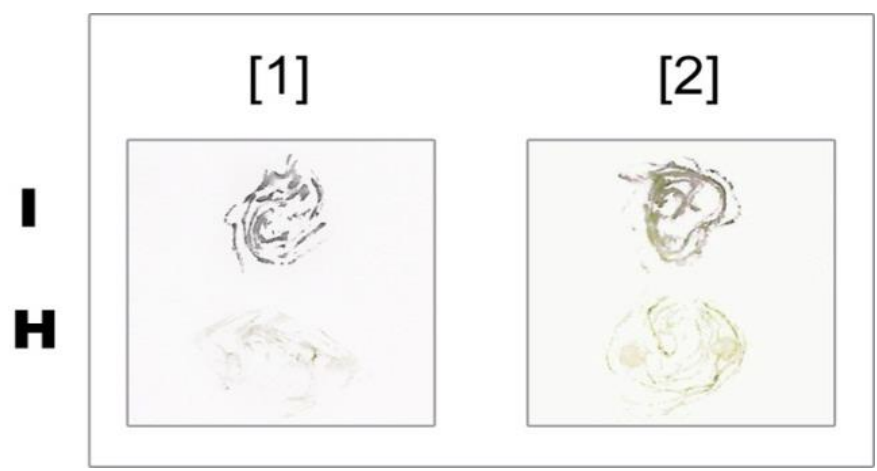

Figure 5 Detection of CPMV in leaves of infected plants blotted on the unused face of previously processed nitrocellulose membrane, [1] nitrocellulose membrane used 7 years ago; [2] nitrocellulose membrane used 11 years ago. I Infected plant tissue, $\mathrm{H}$. Healthy plant tissue.

Detection of CPMV, ToMV and ZYMV in infected plants after different periods of inoculation

Obtained results showed that CPMV, ToMV and ZYMV could be detected by TBIA in infected leaves after 2, 4, 6, 8 and 16 days of mechanical inoculation when using NCM and Canson paper $\left(300 \mathrm{~g} / \mathrm{m}^{-2}\right)$ (Fig. 6).

\section{CpMV TolMV}

\section{ZYMV}

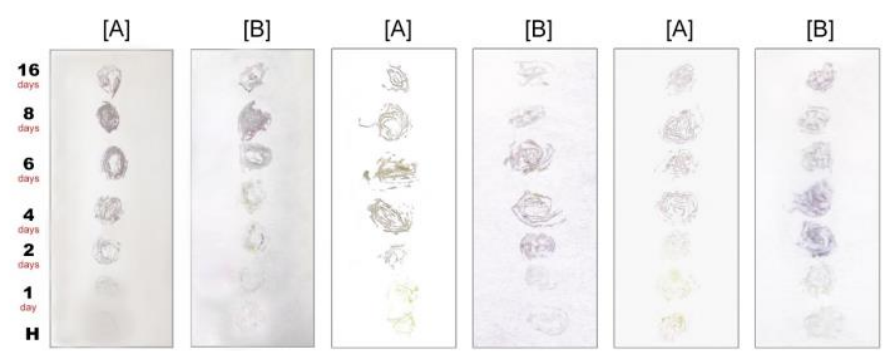

Figure 6 Detection of CPMV, ToMV and ZYMV in leaves of infected plants after different periods of inoculation blotted on, [A]. Nitrocellulose membrane, [B]. Canson paper $\left(300 \mathrm{~g} / \mathrm{m}^{2}\right)$, H. Healthy plant tissue.

\section{Detection of CPMV, ToMV and ZYMV in different parts of infected plants}

TBIA conducted to detect CPMV, ToMV and ZYMV in infected leaves, petioles, stem and roots gave significant results with NCM and Canson paper $\left(300 \mathrm{~g} / \mathrm{m}^{-2}\right)$ (Fig. 7).

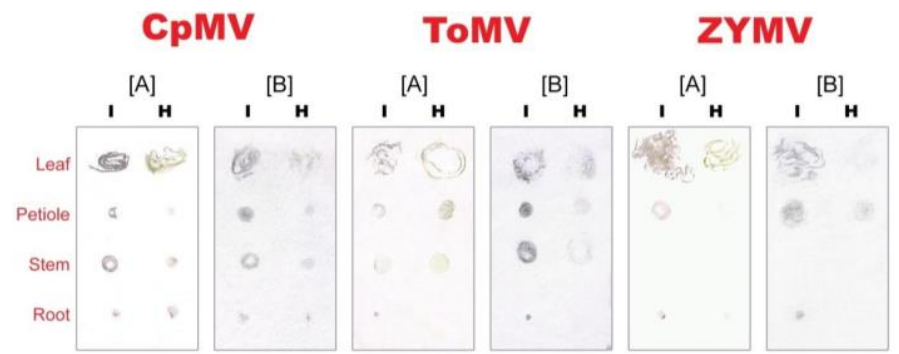

Figure 7 Detection of CPMV, ToMV and ZYMV in different parts of infected plants (leaf, petiole, stem and root) blotted on, [A]. Nitrocellulose membrane, [B]. Canson paper $\left(300 \mathrm{~g} / \mathrm{m}^{2}\right)$. I. Infected plant tissue, H. Healthy plant tissue.

\section{Detection of ToMV in naturally infected plants}

As shown in Figure (8), ToMV could be clearly detected using both NCM and Canson paper $\left(300 \mathrm{~g} / \mathrm{m}^{-2}\right)$ in naturally infected tomato plant samples. 


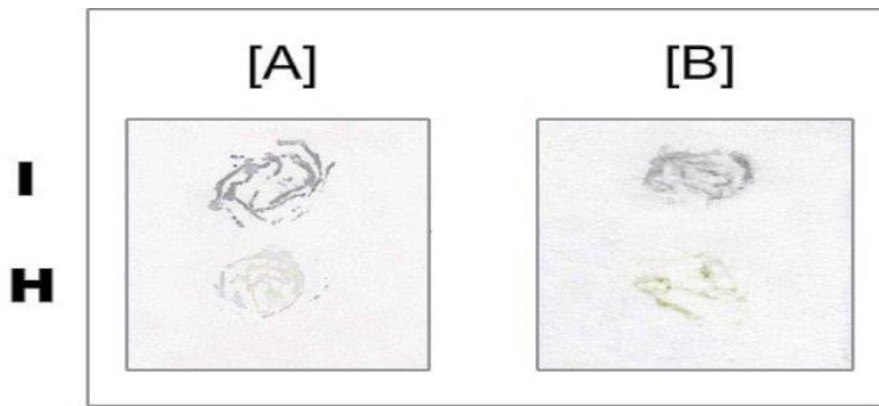

Figure 8 Detection of ToMV in leaves of naturally infected tomato plants blotted on, [A]. Nitrocellulose membrane, [B]. Canson paper $\left(300 \mathrm{~g} \mathrm{~m}^{-2}\right)$. I. Infected plant tissue, H. Healthy plant tissue.

\section{DISCUSSION}

The availability of sensitive and efficient detection techniques is one of the keys to successful use of viral disease control strategy. Since TBIA has great benefits when compare with ELISA in terms of detection time, cost, sensitivity and convenience, it has been applied for diagnosis of many viral diseases (Jeong $\boldsymbol{e}$ al., 2014). TBIA can perform mass analysis of plant samples directly in field, which can be processed later. It is proposed as reliable alternative to ELISA in large scale survey studies (Hu et al., 1997; Djelouah et al., 2014). It has usefu application for detection of naturally infected faba bean plants when compared with indirect ELISA (Kawanna and Fegla, 2015). Direct tissue blot immunoassay (DTBIA) can detect the presence of infection of Xyllella fastidiosa in some symptomless olive trees (Djelouah et al., 2014) and pineapple closterovirus (PCV) in symptomless pineapple plants in the field (Hu et al., 1997).

The present study results showed that, most of the tested papers recorded positive results with the tested viruses except in case of high glossy photo paper $\left(200 \mathrm{~g} / \mathrm{m}^{2}\right)$ which did not show any infected or healthy tissue print. Filter paper (Whatman No. 1), local drawing paper $\left(60 \mathrm{~g} / \mathrm{m}^{2}\right)$, photocopy paper $\left(80 \mathrm{~g} / \mathrm{m}^{2}\right)$, $\left(56 \mathrm{~g} / \mathrm{m}^{2}\right)$ and $\left(70 \mathrm{~g} / \mathrm{m}^{2}\right)$ were very gentle and need high caring in handling during the steps of the method. The aforementioned results are in line with Makkouk and Kumari (2002) study results where they got the same observation with filter and photocopy paper when tested to detect Alfalfa mosaic virus (AMV), Bean yellow mosaic virus (BYMV) in faba bean and Barley yellow striate mosaic virus (BYSMV) in barley. Filter paper, local drawing paper $\left(60 \mathrm{~g} / \mathrm{m}^{2}\right)$, photocopy paper $\left(80 \mathrm{~g} / \mathrm{m}^{2}\right),\left(56 \mathrm{~g} / \mathrm{m}^{2}\right)$ and $\left(70 \mathrm{~g} / \mathrm{m}^{2}\right)$ may did not persist to chemicals exposure during the assay steps. Meanwhile, NCM paper and Canson paper $\left(150 \mathrm{~g} / \mathrm{m}^{2}\right.$ and $300 \mathrm{~g} / \mathrm{m}^{2}$ ) were persist in good condition during the process. Background in different types of paper except NCMs and Canson papers was took place. The reaction of the tested papers may be differed according to its component and structure. The NCM is characterized with the hydrophilic nature and has high affinity for binding proteins and the porous structure of it facilitates the fluid to penetrate via capillary action (Suntornsuk and Suntornsuk, 2019). High glossy photo paper used for inkjet printings, has smooth, glossy and waterproof surface. Thus, it may have not the ability to absorb the antigen or the antibody.

NCM is relatively expensive and represents $40-50 \%$ of TBIA supplementary cost, which limits its use for virus detection in large scale, especially in the developing countries. Canson paper; fine art paper was more economical because it was cheaper than the NCM.

Previous studies working with dot blot immunoassay (DBIA) found that plain paper could be used as a solid support with the equal sensitivity to NCM for detection of some potato viruses (Heide and Lange, 1988) and suitable for testing pea seed-borne mosaic potyvirus, pea early browning tobravirus, bean common mosaic potyvirus, barley stripe mosaic hordeivirus and squash mosaic comovirus (Lange et al., 1989). In the same line, to evaluate a substitute for nitrocellulose membrane used for testing the latent infection of bacterial wilt of potato, promising results were given with Cactus xerox paper, ordinary xerox paper and Vernal mimeographing paper (substance 20) which are similar as that of NCM (Mariano et al., 1995).

Since, Canson paper $\left(150 \mathrm{~g} / \mathrm{m}^{2}\right.$ and $\left.300 \mathrm{~g} / \mathrm{m}^{2}\right)$ had the ability to detect all the tested viruses as NCM with less background. Therefore, Canson paper $\left(300 \mathrm{~g} / \mathrm{m}^{2}\right)$ was used to examine the sensitivity of using both faces of the paper, the efficiency of Canson paper $\left(300 \mathrm{~g} / \mathrm{m}^{2}\right)$ to detect the tested viruses after different times of inoculation and in different parts of the plant. Also, the ability of Canson paper to detect the viral infection in naturally infected samples.

Printing both faces of NCM or Canson paper $\left(300 \mathrm{~g} / \mathrm{m}^{2}\right)$ gave noticeable purple colour with CPMV, ToMV and ZYMV in infected leaves. Using both faces of NCM or Canson paper reduced the cost of the test by $50 \%$.

The results indicated the possibility of using the unused face of NCM even after 7 years or 11 years of processing for detection of CPMV. These results reflect the potency of the previously used NCM after long times of processing and indicated that NCM could persist the subjection to harsh chemical treatments. The present study results confirmed the previous findings of Al-Khalaf $\boldsymbol{e t}$ al. (2009) who worked on Bean yellow mosaic virus (BYMV) by using both sides of membrane for processed and un-processed NCM.

As regard to the assessment of the sensitivity of Canson paper when compared with NCM in the detection of the tested viruses after different periods of inoculation, NCM and Canson paper showed the same sensitivity for detection of the tested viruses after different periods of inoculation as $2,4,6,8,16$ days of inoculation.

Good sensitivity was obtained with Canson paper $\left(300 \mathrm{~g} / \mathrm{m}^{2}\right)$ as NCM for the detection of all the tested viruses in different plant tissues; leaves or petiole or stems and roots. The results predicated the possibility of using Canson paper for the studying of the distribution of the virus in the infected plants, also in the asymptomatic plants.

Our results indicated that, Canson paper $\left(300 \mathrm{~g} \mathrm{~m}^{-2}\right)$ could efficiently detected ToMV in natural infected tomato samples as NCM. Thus, TBIA using Canson paper could be applied for field survey studies, however large scale of samples tested with relatively low cost.

\section{CONCLUSION}

The present study concluded from the recorded data results the possibility of replacement of the nitrocellulose membrane by the Canson paper $\left(300 \mathrm{~g} / \mathrm{m}^{2}\right)$, in addition to the usage in its two faces. Also, using of the other side of the previously used nitrocellulose membrane in the detection which led to pronounced reduction of the cost and increase the applicability of TBIA.

Acknowledgement:The authors would like to thank the late Prof. Gaber Ibrahim Fegla, Plant Pathology Department, Alexandria University, Egypt for his suggestions of the manuscript.

Conflict of interest: The authors declare that they have no conflicts of interest in the research.

Human and animal rights: This article does not contain any studies with human participants or animals performed by any of the authors.

\section{REFERENCES}

Aboul-Ata, A.E., Mazyad, H., El-Attar, A.K., Solyman, A.M., Anfoka, G., Zeidaen, M., Gorovits, R., Sobol, L. \& Czosnek, H. (2011). Diagnosis and control of cereal viruses in the Middle East. Advances in Virus Research, 81, 3361. https://doi.org/10.1016/B978-0-12-385885-6.00007-9

Al-Khalaf, M., Kumari, S.G., Haj Kasem, A.A., Makkouk, K.M. \& Al-Chaabi, S, (2009). Use of the two faces of nitrocellulose membrane in tissue blot immunoassay for the detection of Bean yellow mosaic virus and the possibility of its mechanically transmitted from the printed membrane to the host plant. Arab Journal of Plant Protection, 27, 91-94.

Bin, Y., Song, Z., Li, Z.A \& Zhou, C.Y. (2015). Direct tissue blot immunoassay for detection of Citrus yellow vein clearing virus.

Acta Horticulturae Sinica

$42(9), 1843-1850$

http://www.ahs.ac.cn/EN/10.16420/j.issn.0513-353x.2015-0263

Broadbent, L. (1976). Epidemiology and control of tomato mosaic virus. Annual Review of Phytopathology, 14,75-96. https://doi.org/10.1146/annurev.py.14.090176.000451

Desbiez, C. and Lecoq, H. (1997). Zucchini yellow mosaic virus. Plant Pathology, 46,809-829. https://doi.org/10.1046/j.1365-3059.1997.d01-87.x

Djelouah, K., Frasheri, D., Valentini, F., D'Onghia, A.M. \& Digiaro, M, (2014). Direct tissue blot immunoassay for detection of Xylella fastidiosa in olive trees. $\begin{array}{lll}\text { Phytopathologia Mediterranear } & \text { 53(3),559-564. }\end{array}$ https://doi.org/10.14601/Phytopathol_Mediterr-14603

D’Onghia, A..M, Djelouah, K., Frasheri, D. \& Potere, O. (2001). Detection of Citrus psorosis virus by direct tissue blot immunoassay. Journal of Plant Pathology, 83(2),139-142. https://dx.doi.org/10.4454/ipp.v83i2.1122

Heide, M. \& Lange, L. (1988). Detection of potato leaf roll virus and potato viruses $\mathrm{M}, \mathrm{S}, \mathrm{X}$ and $\mathrm{Y}$ by dot immunobinding on plain paper. Potato Research, 31(3), 367-373

Hsu, H.T. (2009). Development of enzyme linked, tissue blot and dot blot immunoassays for plant virus detection. In: Burns, R. (eds) Plant Pathology. Methods in Molecular Biology (Methods and Protocols), Vol 508,15-25. Humana Press, Totowa, NJ https://doi.org/10.1007/978-1-59745-062-1_2

Hsu, H.T. \& Lawson, R.H. (1991). Direct tissue blotting for detection of tomato spotted wilt virus in Impatiens. Plant Disease, 75, 292-295. http://dx.doi.org/10.1094/PD-75-0292

Hu, J.S., Sether, D.M., Liu, X.P. \& Wang, M. (1997). Use of tissue blotting immunoassay to examine the distribution of pineapple closterovirus in Hawaii. Plant Disease, 81, 1150 -1154. https://doi.org/10.1094/PDIS.1997.81.10.1150

Jeong, J., Ju, H. \& Noh, J. (2014). A review of detection methods for the plant viruses. Research in Plant Disease, 20(3), 173-181.

http://dx.doi.org/10.5423/RPD.2014.20.3.173

Kammen, A.V., Lent, J.V. \& Wellink, J. (2001). Description of plant viruses. "Cowpea mosaic virus" http://www.dpvweb.net/dpv/showdpv.php?dpvno=378 
Kawanna, M.A. \& Fegla, G.I. (2015). Comparison between indirect ELISA and TBIA for detection of some viruses in naturally infected faba bean plants. Annual Research \& Review in Biology, 7(4), 275-282. https://doi.org/10.9734/ARRB/2015/19181

Lange, L., Jomantor, A. \& Heide, M. (1989). Testing seeds for viruses by dot immunobinding (DIB) directly on plain paper. Tidsskrift för Planteavl, 93(1),9396.

Li, R., Baysal-Gurel, F., Abdo, Z., Miller, S.A. \& Ling, K. (2015). Evaluation of disinfectant to prevent mechanical transmission of viruses and a viroid in https://doi.org/10.1186/s12985-014-0237-5

Lin, N.S., Hsu, Y.H. \& Hsu, H.T. (1990). Immunological detection of plan viruses and mycoplasma like organism by direct tissue blotting on nitrocellulose membrane. Phytopathology, 80(9),824-828. https://doi.org/10.1094/phyto-80-824 Makkouk, K.M. \& Kumari, S.G. (2002). Low-cost paper can be used in tissueblot immunoassay for detection of cereal and legume viruses. Phytopathologia Mediterrenea, 41, 275-278. https://doi.org/10.14601/Phytopathol_Mediterr-1683 Makkouk, K.M., Hsu, H.T. \& Kumari, S.G. (1993). Detection of three plant viruses by dot-blot and tissue-blot immunoassays using chemiluminescent and chromogenic substrates. Journal of Phytopathology, 139(2),97-102. https://doi.org/10.1111/j.1439-0434.1993.tb01405.x

Mariano, J., Dar, J. \& Lorezco, T. (1995). Local papers as substitute for nitrocellulose membrane in the detection of bacterial wilt latent infection of potato. Philippine Journal of Plant Industry (Philippines), 60, 41-45.

Suntornsuk, W. \& Suntornsuk, L. (2019). Recent applications of paper-based point-of-care devices for biomarker detection. Electrophoresis,1-19. https://doi.org/10.1002/elps.201900258 